\title{
THE USE OF GIS FOR THE APPLICATION OF THE PHENOMENOLOGICAL APPROACH TO THE SEISMIC RISK ANALYSIS: THE CASE OF THE ITALIAN FORTIFIED ARCHITECTURE
}

\author{
E. Lenticchia ${ }^{a}$ and E. Coïsson ${ }^{b *}$ \\ ${ }^{\text {a }}$ Politecnico di Torino - Department of Structural, Geotechnical and Building Engineering, Corso Duca degli Abruzzi 24, 10129 - \\ Turin, Italy. E-mail: erica.lenticchia@polito.it \\ ${ }^{\mathrm{b}}$ Università degli Studi di Parma - Department of Engineering and Architecture, Viale delle Scienze 181/A, 43100 - Parma, Italy. \\ E-mail: eva.coisson@unipr.it
}

Commission VI, WG VI/4

KEY WORDS: GIS, phenomenological approach, fortified architecture, damage mechanisms, castles, fortresses

\begin{abstract}
:
The present paper proposes the use of GIS for the application of the so-called phenomenological approach to the analysis of the seismic behaviour of historical buildings. This approach is based on the awareness that the different masonry building typologies are characterized by different, recurring vulnerabilities. Thus, the observation and classification of the real damage is seen as the first step for recognizing and classifying these vulnerabilities, in order to plan focused preventive interventions. For these purposes, the GIS has proven to be a powerful instrument to collect and manage this type of information on a large number of cases.

This paper specifically focuses on the application of the phenomenological approach to the analysis of the seismic behaviour of fortified buildings, including castles, fortresses, citadels, and all the typical historical constructions characterized by the presence of massive towers and defensive walls. The main earthquakes which struck Italy in the last 40 years (up to the recent Central Italy seismic swarm) were taken into consideration and described by means of shake maps. A previously published work has been continued with the addition of new data and some improvements, including a specific symbology for the description of building typologies and conservation status on the maps, the indications of damage levels and the comparison between shake maps in terms of pga and in terms of pseudo-acceleration. The increase in knowledge obtained and the broader frame given by the analysis of the data are here directed to the primary aim of cultural heritage preservation.
\end{abstract}

\section{INTRODUCTION}

\subsection{The GIS for cultural heritage management}

The use of Geographic Information System (GIS) for the archival, analysis and representation of geographic information has become a consolidated tool in different scientific fields. Also in the field of architectural heritage, the GIS technology is used to join and relate data coming from different disciplines involved in documentation and maintenance processes of Cultural Heritage assets(MIBACT2015). In Italy the Ministry of Cultural Heritage has introduced a GIS specifically for the risk management of cultural heritage (MIBACT 2016), but it is more focused on the definition of seismic and geo-morphological hazard levels than to the definition of the vulnerability, which is only related to the conservation status; moreover, no specific data are reported on the damages suffered in previous earthquakes. Some GIS have been applied specifically to fortified buildings: Monti (2006) on the Emilia-Romagna castles and Deidda et al. (2015) for the Sardinia coastal towers, among others, but they have no specific reference to the seismic issue or to the damage they show. The first work that applied GIS for the seismic damage and behaviour of fortifies architecture is Coisson et al (2016). The present paper continues this work with more data and some improvements. In particular, the last Central Italy seismic swarm, up to the January 2017 events, has been included with specific on site surveys, and the number of castles overall considered has increased, with a better selection of the case studies.

\subsection{The phenomenological approach in the seismic field}

In particular, the present paper proposes the use of GIS for the application of the so-called phenomenological approach to the analysis of the seismic behaviour of historical buildings. This approach is based on the awareness that the different masonry building typologies are characterized by different, recurring vulnerabilities. Thus, the observation and classification of the real damage is seen as the first step for a focused preventive intervention. This approach was first applied on a systematic base in Italy to the study of the effects of the Friuli 1976 earthquake on churches (Doglioni et al., 1994). This work later became the base for the introduction of the table of recurring damage mechanisms for churches in the latest Italian technical code for the protection of cultural heritage from the seismic risk (Guidelines 2007), recognizing its validity. The GIS is here proposed as a powerful instrument to collect and manage this type of information on a large number of cases, increasing the effectiveness of the approach.

The present work specifically focuses on the application of the phenomenological approach to the analysis of the seismic behaviour of fortified buildings, including castles, fortresses, citadels, and all the typical historical constructions characterized by the presence of towers and defensive walls. These buildings, despite being a meaningful element of the architectural landscape, have been subjected to limited studies compared to other building typologies, as far as the specific seismic damages are concerned, and mostly regarding single case studies (Tiberti et al. 2016, Castellazzi et al. 2015, Coïsson

\footnotetext{
* Corresponding author
} 
et al. 2016a, Meschini et al 2015, Barrile et al. 2016, Leoni et al. 2015). Only since the 2012 Emilia earthquake, a more systematic approach was applied with the definition of a table for the recurring damage mechanisms specific for the fortified buildings damaged in that occasion (Cattari et al, 2012 and Cattari et al., 2014). The validity of the table was then widened by the following work of Coisson et al (2016), which is at the base of the present paper.

\subsection{The fortified architecture typologies}

Fortified architecture is a generic term, which can indicate a very wide variety of buildings, usually characterized by the presence of towers and defensive walls, but with features varying depending on the geographic area, on the materials availability, on the history, on the importance and specific use of the construction. In an attempt of cataloguing these possible variations, Perogalli (Fig. 1) has identified 16 different types of fortified buildings, form castles to fortified bridges, and proposed specific symbols to represent them in maps. Furthermore, to represent the consistency, he proposed to plot them with a black dotted line (historical traces), black line with white hatch (ruins) or black hatch (entire). He also proposed an additional symbol, to be designed below the typological symbol, to describe the maintenance state. For our purposes, the historical traces were not taken into consideration and the two parameters of consistency and maintenance were merged into the global concept of state of conservation, with a specific symbology (Fig. 2) which derives from the ones proposed by Perogalli. Indeed, being the vulnerability to seismic damage the main objective of the research, a good maintenance in a ruined castle has not the same implications as a good maintenance in an entire fortress. Starting from Perogalli's proposal, thus, the symbols have been modified as indicated in Figure 2 and have been inserted in the GIS software. Moreover, in case of buildings damaged by the earthquake, the black colour has been replaced with a white one. Figure 3 shows the use of the typology symbols for the Central Italy earthquakes whereas Figure 3 shows the state of conservation for the same fortified buildings.

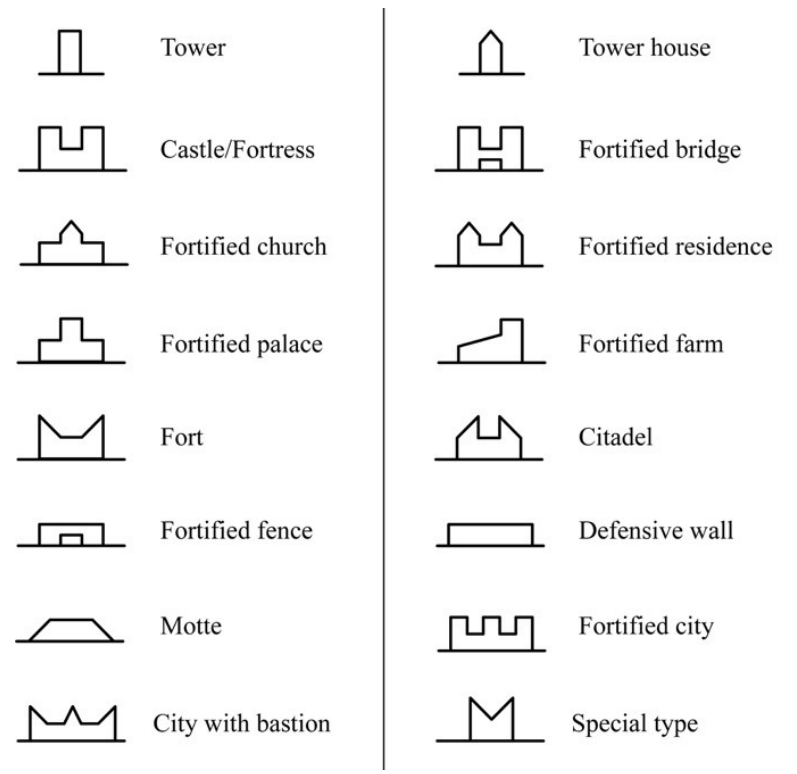

Figure 1. Castle and fortified building typologies from Perogalli and Istituto Italiano dei Castelli (Perogalli C., 1972)

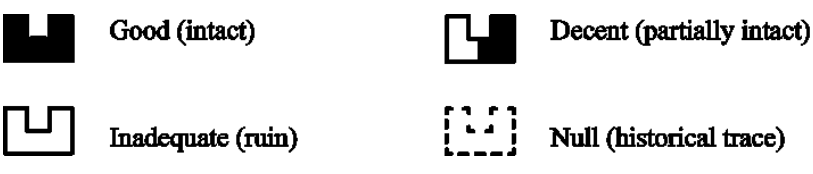

Figure 2. A proposal for the symbology regarding the state of conservation of fortified buildings

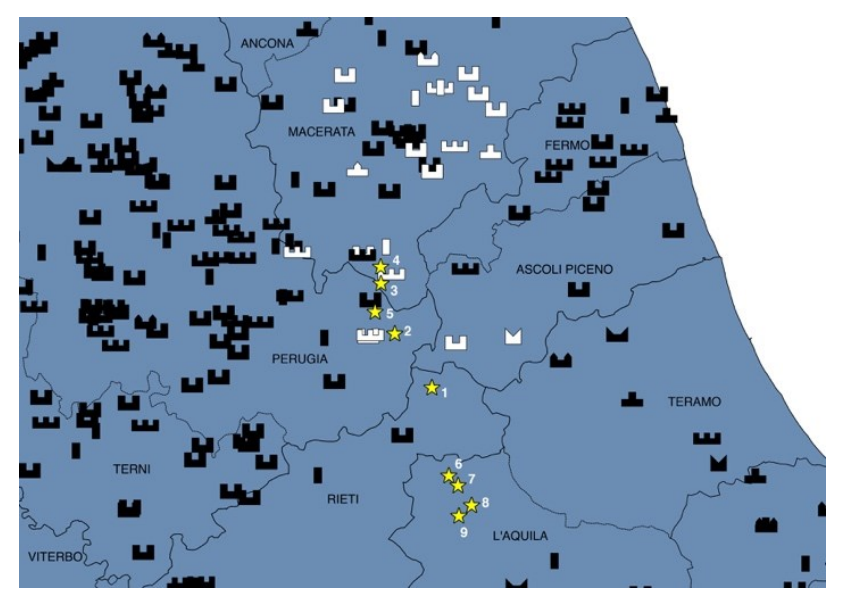

Figure 3. Map of Central Italy with the fortified buildings represented with symbols for the different typologies. The damaged buildings are coloured in white.

\section{THE PROPOSED APPROACH}

The main seismic events which struck Italy in the last 40 years have been analysed in Coisson et al. (2016). In this paper the analysis is widened (Fig. 4) with the inclusion of the recent Central Italy earthquake 2016-17, that has damaged a large number of buildings, some of which were already affected by the Umbria-Marche earthquake of 1997. For instance, a list of the seismic events considered for Central Italy, with date, coordinates of the epicentre and magnitude is shown in Table 1. For each seismic event, the characteristics of the earthquake have been described by means of shake maps.

\begin{tabular}{|l|l|l|l|l|l|}
\hline ID & Region & $\mathbf{M}_{\mathbf{L}}$ & Date & $\begin{array}{l}\text { Time } \\
(\mathrm{UTC})\end{array}$ & $\begin{array}{l}\text { Depth } \\
(\mathrm{km})\end{array}$ \\
\hline 1 & Central Italy & 6.0 & $08 / 24 / 2016$ & $01: 36: 32$ & 8.1 \\
2 & 2016 & 5.4 & $08 / 24 / 2016$ & $02: 33: 29$ & 5.0 \\
3 & & 5.4 & $10 / 26 / 2016$ & $17: 10: 37$ & 8.7 \\
4 & & 5.9 & $10 / 26 / 2016$ & $19: 18: 08$ & 8.4 \\
5 & & 6.5 & $10 / 30 / 2016$ & $06: 40: 17$ & 9.0 \\
6 & Central Italy & 5.1 & $01 / 18 / 2017$ & $09: 25: 40$ & 6.0 \\
7 & 2017 & 5.5 & $01 / 18 / 2017$ & $10: 14: 09$ & 5.0 \\
8 & & 5.4 & $01 / 18 / 2017$ & $10: 25: 23$ & 6.0 \\
9 & & 5.0 & $01 / 18 / 2017$ & $13: 33: 36$ & 6.0 \\
\hline \multicolumn{3}{|c|}{ Table 1. Seismic events considered for Central-Italy $2016-17$}
\end{tabular}




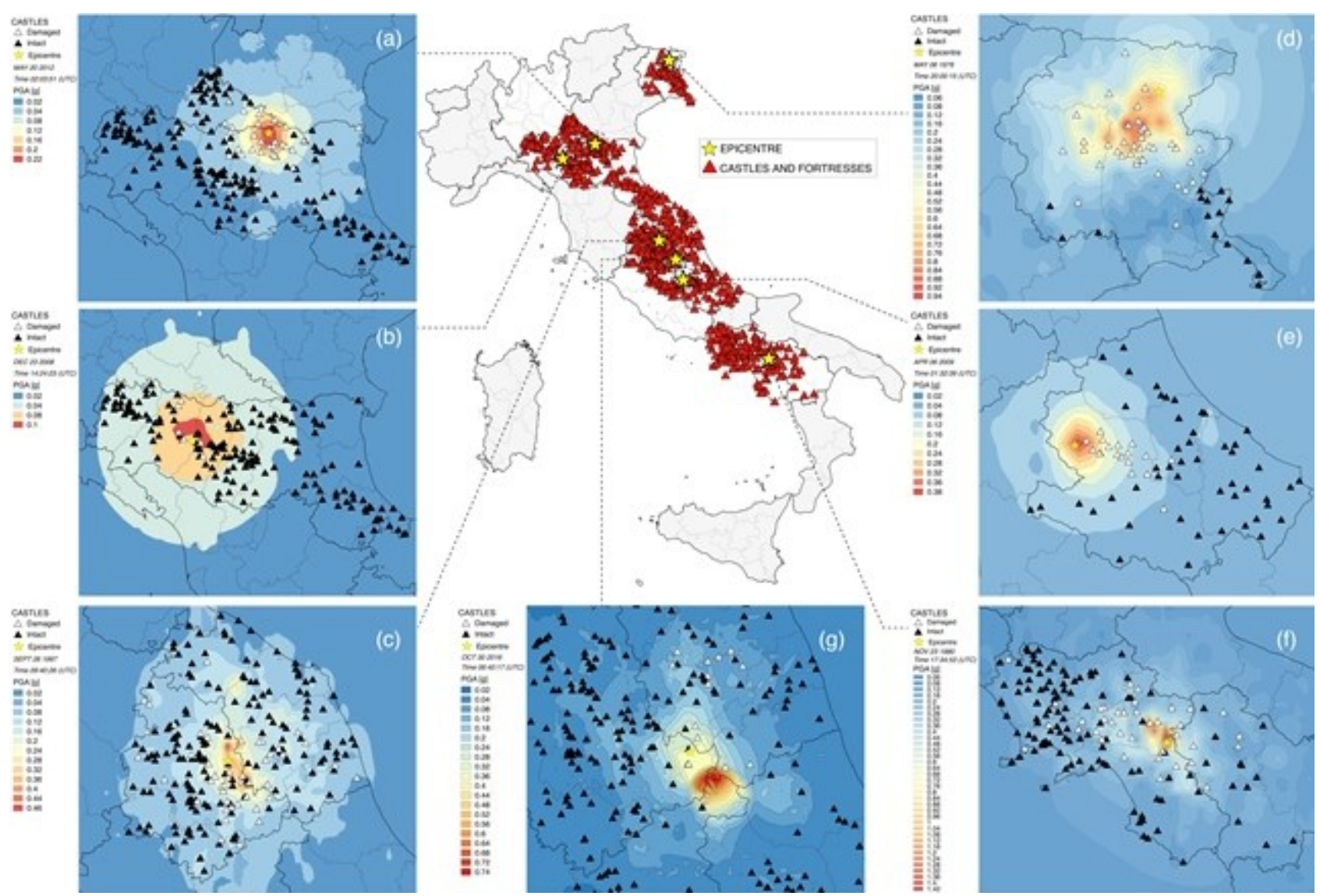

Figure 4. Map of Italy with the investigated fortified buildings. The map is surrounded by the shakemaps (pga) of the main seismic events.

\subsection{Shake Maps}

A ShakeMap is a representation of ground shaking produced by an earthquake. The information it presents is different from the earthquake magnitude and epicenter that are released after an earthquake because ShakeMap focuses on the ground shaking produced by the earthquake, rather than the parameters describing the earthquake source. So, while an earthquake has one magnitude and one epicenter, it produces a range of ground shaking levels at sites throughout the region depending on distance from the earthquake, the rock and soil conditions at sites, and variations in the propagation of seismic waves from the earthquake due to complexities in the structure of the Earth's crust. The shake maps can be generated not only in terms of peak ground acceleration, but also in terms of velocity, pseudoaccelerations or even an instrumentally-derived, estimated Modified Mercalli Intensity map. This map makes it easier to relate the recorded ground motions to the expected felt and damage distribution. The Instrumental Intensity map is based on a combined regression of recorded peak acceleration and velocity amplitudes. In the present paper, a comparison between the different shake maps in terms of effectiveness in representing the real damage on the fortified architecture is carried out.

With the current Italy station distribution, data gaps are common, particularly for smaller events and events near or outside the edge of the network. In order to stabilize contouring and minimize the misrepresentation of the ground motion pattern due to data gaps, some values were predicted in areas without data. Given the epicenter and magnitude, peak motion amplitudes in spare regions are estimated from the Joyner, Boore, and Fumal (1997), and Joyner and Boore (1988) attenuation curves.

In pga maps, the peak horizontal acceleration at each station is contoured in units of percent-g (where $g=$ acceleration due to the force of gravity $=981 \mathrm{~cm} / \mathrm{s} / \mathrm{s}$ ). The peak values of the vertical components are not used in the construction of the maps because they are, on average, lower than the horizontal amplitudes and ground motion prediction equations used to fill in data gaps between stations are based on peak horizontal amplitudes. The contour interval varies greatly and is based on the maximum recorded value over the network for each event.

For moderate to large events, the pattern of peak ground acceleration is typically quite complicated, with extreme variability over distances of a few $\mathrm{km}$. This is attributed to the small scale geological differences near the sites that can significantly change the high-frequency acceleration amplitude and waveform character. Although distance to the causative fault clearly dominates the pattern, there are often exceptions, due to local focussing and amplification. This makes interpolation of ground motions at one site to a nearby neighbour somewhat risky. Peak acceleration pattern usually reflects what is felt from low levels of shaking up to moderate levels of damage.

For the present work, the shake maps were taken from the USGS archives (USGS 2016), except for Central Italy events, for which they have been loaded from the INGV archive (Shakemap Working Group 2016). Shake maps of two different variables have been considered: peak ground acceleration pga, and spectral acceleration psa. 


\subsection{The GIS}

The geodatabase was created using the open source software QGIS version 2.12 (QGIS Development Team 2015).

As ShakeMap processing does not occur in a Geographic Information System (GIS), a specific post-processing of the grid file into shapefiles was carried out for direct import into GIS. In this application, the shapefiles are contour polygons of the peak ground-motion amplitudes. These contour polygons are actually equal-valued donut-like polygons that sample the contour map at fine enough intervals to accurately represent the surface function (Fig. 5). The shapefiles independent of a GIS are generated using a shareware package which employs a 4-point method for contouring.

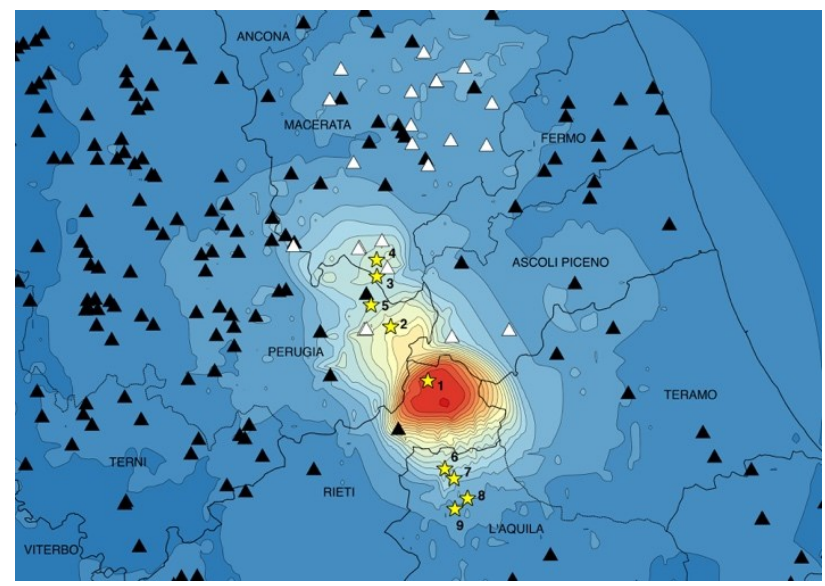

Figure 5. Shakemap (pga) of Central Italy (first seismic event in

Tab. 1) with fortified buildings. The damaged buildings are white and epicentres are represented with stars.

\subsection{The damage data collection}

More than 750 castles in the areas struck by the considered earthquakes have been identified and inserted into the specifically formulated GIS. Then, a thorough archival and in situ observation of the damages suffered by the most significant case histories was made, to collect the main information needed for the application of the empirical approach. Based upon a previously defined damage mechanisms table, represented in Fig. 8 for completeness, the type of damage suffered by each fortress in the GIS was analysed and classified, to make some considerations on the distribution of the different mechanisms on the territory, in relation with the different characteristics in terms of soil, materials, building typologies, and conservation status. For a more immediate visual observation of the relation between level of damage and seismic action, as previously indicated, a specific graphic markers for the level of damage and for building features (typology, conservation status, materials) was defined and adopted. For each earthquake, a table was filled in with all the affected fortified buildings, with province, identification number, and name. The type of masonry (solid clay bricks, stone units or rubble masonry, tuff units, mixed) and the geometry of the base of the towers (none, circular, rectangular, irregular) were also reported, together with the presence of merlons and protruding elements, such as pepper-pot turrets. The state of conservation at the time of the seism (ruin, used, abandoned) was reported. The value of pga max and $I$ max obtained by querying the GIS shakemaps and the soil morphology (plain, soft slope, strong slope, and crest) were inserted. Lastly, the table was filled by numbers from 0 (no damage) to 5 (collapse), which represent the level of damage.

\subsection{The data analysis}

For the recent Central Italy seismic events, characterized by many subsequent shocks of large intensity, with epicentres several kilometres apart, a more in depth analysis was carried out. A description of the seismic event can be found in Michele et al., 2016.

Looking at the Figure 6, it is possible to observe that the area struck by the whole Central Italy sequence of earthquakes is vast and some fortresses that survived the first shock, have been damaged subsequently. For this reason, it was necessary to inspect, for each point of the map, which of the many seismic events occurred had produced the strongest effects. Therefore, the envelope of the seismic actions was calculated for all the considered area. In particular, the 9 shake maps of the events with magnitude $I_{M} \geq 5$ have been superimposed by means of the GIS software, thus obtaining the shake map of maximum pga represented in Figure 6.

This first analysis on the peak ground acceleration maps showed some inconsistencies with the observed damage distribution levels (in the upper part of the map in Fig. 6). For this reason, also the maps of maximum pseudo-acceleration were computed both for structures with a first period of $0.3 \mathrm{~s}$. As pointed out in Cattari (2014), the period of 0.3 is typical of massive masonry In this case, it is possible to observe a "peninsula" that reaches the upper left part of the map, explaining the damage suffered in this area (Fig. 7).

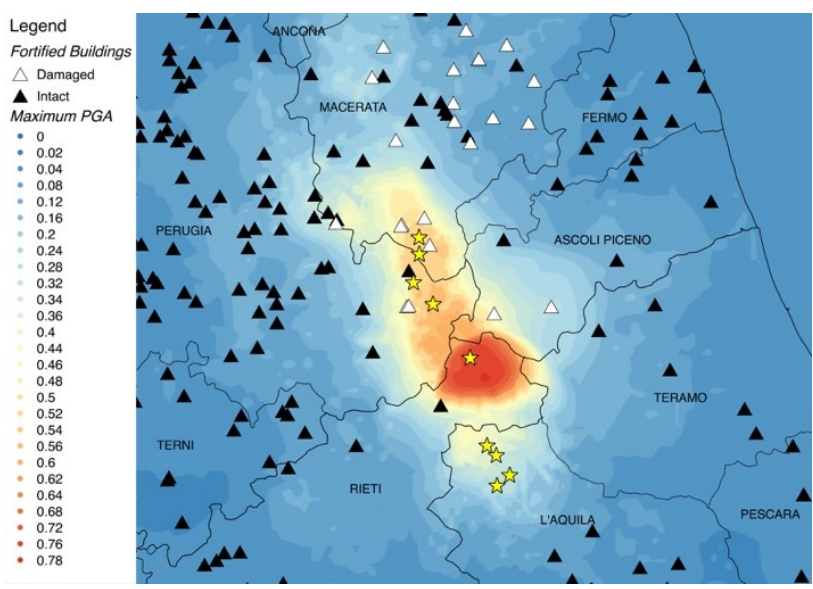

Figure 6. Interpolation of the pga's maximum values of the seismic sequence that hit Central Italy since August 2016

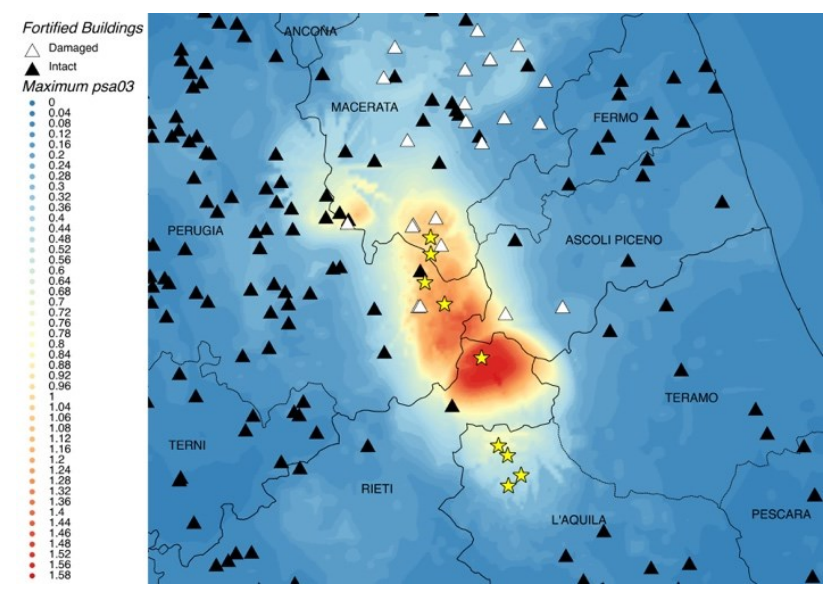

Figure 7. Interpolation of the psa's maximum values with a 0.3 $\mathrm{s}$ period, of the seismic sequence that hit Central Italy since August 2016. 


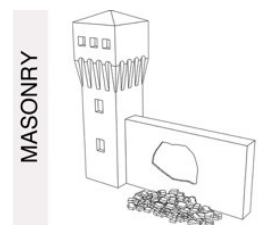

$1 \mathrm{a}$

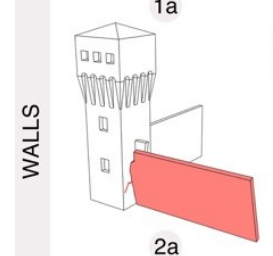

$2 a$

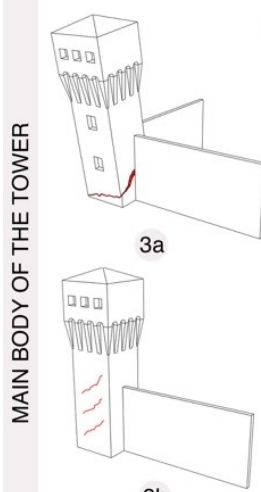

$3 b$

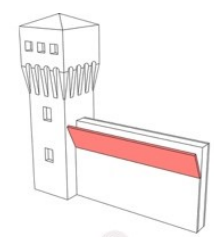

$1 \mathrm{~b}$

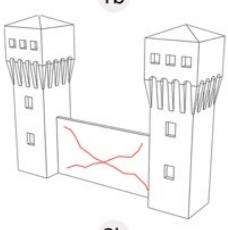

$2 b$

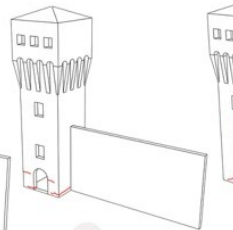

$3 a$

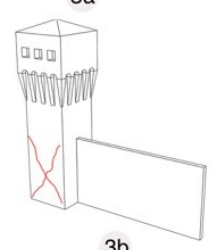

$3 b$

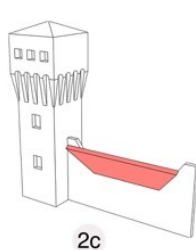

2c

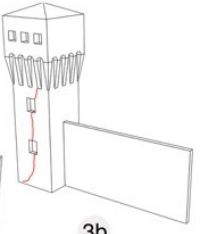

3

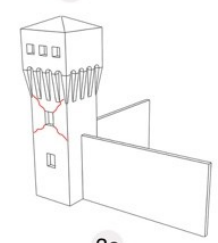

$3 c$

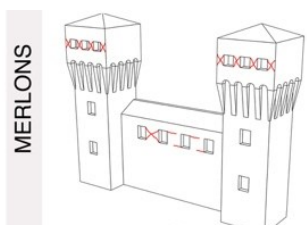

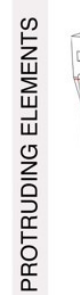

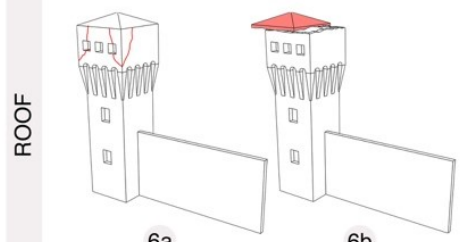

$6 a$

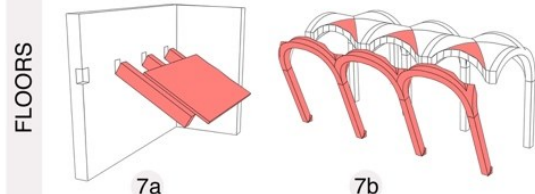

$7 a$

$4 b$
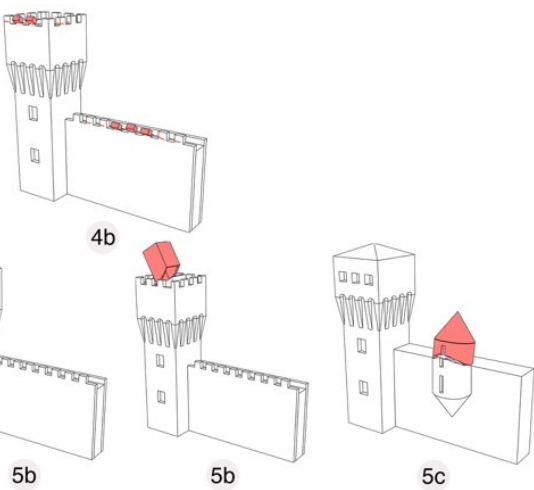

$5 c$

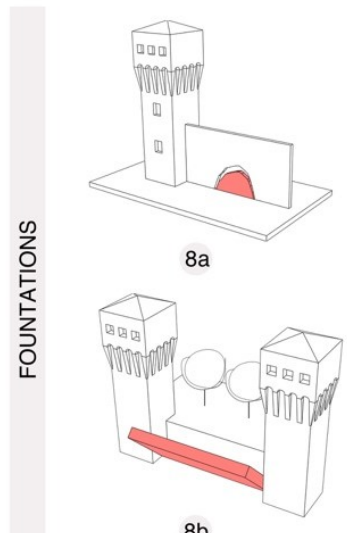

Figure. 8. Table of damage mechanisms (after Coisson et al. 2017)

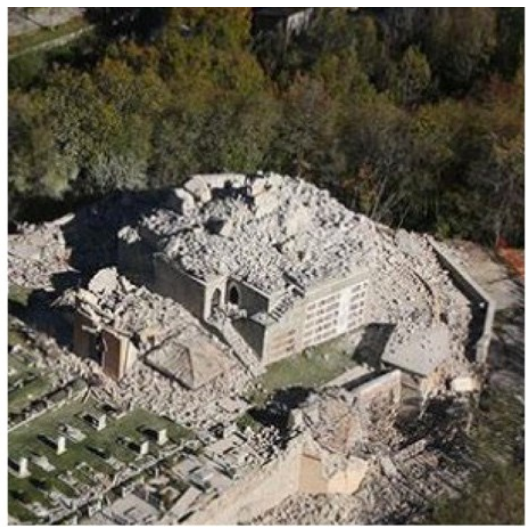

a) Fantellino Castle in Ussita

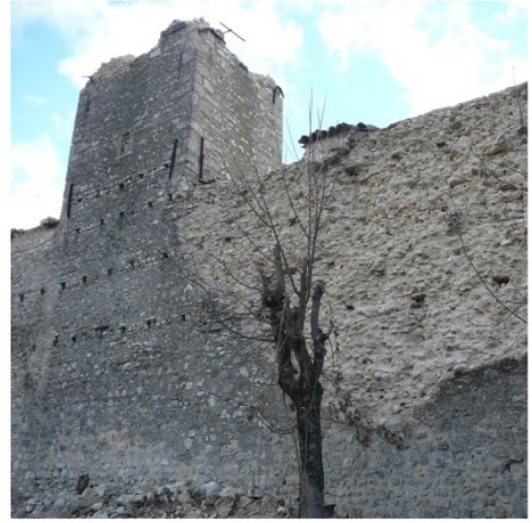

d) Norcia walls, Central Italy 2016

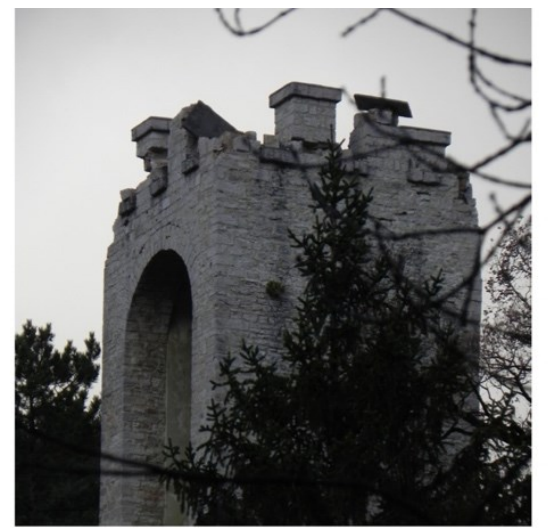

b) Fortified town of Visso

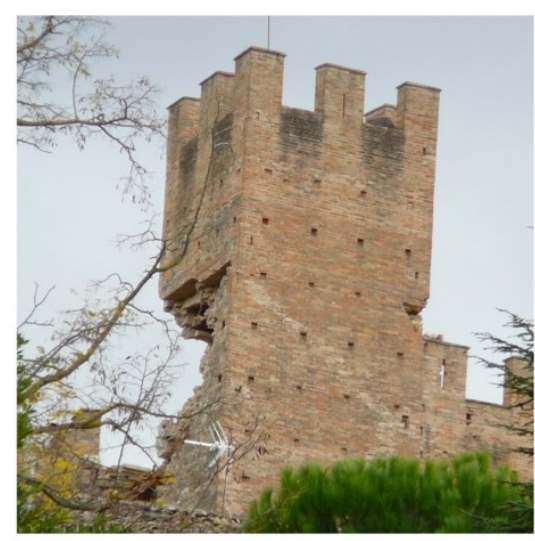

e) Pallotta Castle in Caldarola

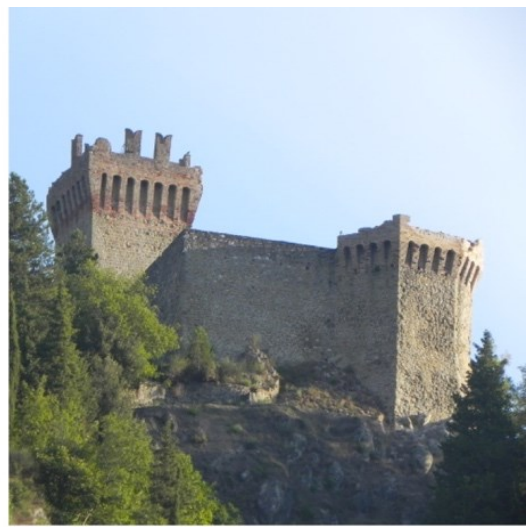

c) Arquata del Tronto Castle

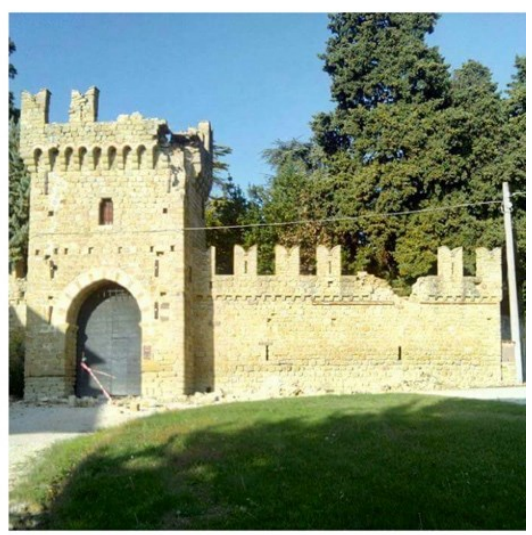

f) Tolentino defensive walls

Figure 9. Damaged fortified buildings after the seismic sequence started in August 2016. 
Lastly, statistical analyses on these data have been conducted in order to inspect possible connections between building features, peak ground acceleration and damage mechanisms (Figure 9). Some of the analyses have already been reported in (Coisson et al 2016), indicating the relative frequency of the damage to the different elements and allowing to identify some threshold values for the damage expected. Moreover, the connection between the damage and the building features is evident, thus allowing to identify the most vulnerable elements on which the interventions should be focused.

\section{CONCLUSIONS}

The paper presents a GIS specifically formulated for the catalogue and analysis of the damage suffered by over 750 fortified architectures hit by large earthquakes in the last 40 years in Italy. For the graphic representation of the analysed buildings, also considering the large variability of the fortified constructions, a specific symbology was developed and applied, derived from the one proposed by Perogalli,

Considering the large number of data to be not only collected but also compared, analysed and subjected to statistical processing, the adoption of a GIS turned out to be particularly suitable for the purpose, allowing to easily link the data about the damage suffered by each analysed building to its specific seismic input obtained through the elaboration of the ShakeMaps, given the strict connection to the geographic location.

This approach, thanks to the direct geographic comparison, allowed to evidence the more strict connection of the damage suffered by the inspected building typologies with the pseudoacceleration with a period of 0,3 rather than with the pga, which is instead the parameter adopted by the Italian technical code for the assessment of the seismic vulnerability and the design of the strengthening.

At last, it should be underlined that the proposed phenomenological approach applied to the fortified architecture, also thanks to the practical functionality of the GIS, supplies a sound tool not only to increase knowledge in this field, but also for the seismic protection of these buildings which characterize the Italian landscape, as it allows to identify the most vulnerable elements which require priority interventions, also in relation to the local expected seismic intensity.

\section{ACKNOWLEDGEMENTS}

The contribution of Daniele Ferretti to the definition of the tables, to the surveys and to the statistical evaluations whose conclusions are reported in the paper is gratefully acknowledged.

\section{REFERENCES}

Amoni D, 1999. Castelli, fortezze e rocche dell'Umbria. Quattroemme, Perugia - Italy (in Italian).

Andreini M, De Falco A, Giresini L, Sassu M, 2014. Structural damage in the cities of Reggiolo and Carpi after the earthquake on May 2012 in Emilia Romagna. Bull Earthq Eng 12(5): 24452480

Badan N, 2013. Le architetture fortificate del Friuli Venezia Giulia colpite dal sisma del 1976. Studi e osservazioni su alcuni interventi realizzati, anche con riferimento alla circolare $n .26$ del 2/12/10 relativa alla valutazione e riduzione del rischio sismico del patrimonio culturale. PhD Thesis, University of Trento, Italy (in Italian).

Barrile V, Bilotta G, D'Amore E, Meduri GM, Trovato S., 2016. Structural modeling of a historic castle using close range photogrammetry. International Journal of Mathematics and Computers in Simulation 10: 370-380

Bartoli G, Betti M, Vignoli A, 2016. A numerical study on seismic risk assessment of historic masonry towers: a case study in San Gimignano. Bull Earthq Eng 14(6): 1475-1518

Biasatti ZP, 2003. Ferite da rimarginare. Il recupero dei beni culturali colpiti dal sisma del 6 maggio 1976. Forum Editrice Universitaria Udinese S.r.l., Udine - Italy (in Italian).

Binda L, Modena C, Casarin F, Lorenzoni F, Cantini L, Munda S., 2011. Emergency actions and investigations on cultural heritage after the L'Aquila earthquake: the case of the Spanish Fortress. Bull Earthq Eng 9: 105-138

Castellazzi G, D’Altri AM, Bitelli G, Selvaggi I, Lambertini A, 2015. From laser scanning to finite element analysis of complex buildings by using a semi-automatic procedure. Sensors (Switzerland) 15(8): 18360-18380

Castellazzi G, D’Altri A M, de Miranda S, Ubertini F, 2017. An innovative numerical modeling strategy for the structural analysis of historical monumental buildings. Eng Struct 132: 229-248

Cattari S, degli Abbati D, Ferretti D, Lagomarsino S, Ottonelli D, Tralli AM, 2012. The seismic behaviour of ancient masonry buildings after the earthquake in Emilia (Italy) on May 20th and 29th, 2012. Ingegneria Sismica 29 (2-3): 87-119.

Cattari S, degli Abbati S, Ferretti D, Lagomarsino S, Ottonelli D, Tralli AM, 2014. Damage assessment of fortresses after the 2012 Emilia earthquake (Italy). Bull Earthq Eng 12: 23332365 .

Chiarizia G, Latini M, Properzi P, 2002. Atlante dei castelli d'Abruzzo. Repertorio sistematico delle fortificazioni. Carsa, Pescara - Italy (in Italian).

Cialone G, Copersino MR, 2013. Sisma Abruzzo 2009 archeologia e terremoto, One Group Edizioni, L'Aquila - Italy (in Italian).

Coïsson E, Ferrari L, Ferretti D, Rozzi M, 2016a, Non-smooth dynamic analysis of local seismic damage mechanisms of the San Felice fortress in Northern Italy. Procedia Engineering 161: 451-457. doi:10.1016/j.proeng.2016.08.589

Coïsson E, Ferretti D, Lenticchia E, 2016b. Italian castles and earthquakes: A GIS for knowledge and preservation. In: K. Van Balen and E. Verstrynge (Eds.), Structural Analysis of Historical Construction SAHC 2016, 12-16 September 2016 , Leuven, CRC Press/Balkema, Leiden. ISBN 9781138029514

Settia AA, 1997. Motte nell'Italia settentrionale, In: Archeologia medievale vol. 24 (1997) p. 439-444.

Lepage JDGG, 2002. Castles and fortified cities of Medieval Europe: an illustrated history, McFarland Co Inc. Pub, Jefferson, North Carolina. 
Coïsson E, Ottoni F., 2012. The problem of large scale evaluation of masonry buildings seismic risk in defining intervention priorities. In: J. Jasienko (Ed.), 8th International Conference on Structural Analysis of Historical Constructions, SAHC 2012, Wroclaw (Poland), Dolnoslaskie Wydawnictwo Edukacyjne (DWE), Wroclaw, Poland, pp. 1449-1456

Colombi M, Borzi B, Crowley H, Onida M, Meroni F, Pinho R, 2008. Deriving vulnerability curves using Italian earthquake damage data. Bull Earthq Eng 6(3): 485-504

Cultrera G, Faenza L, Meletti C, D'Amico V, Michelini A, Amato A., 2014. Shakemaps uncertainties and their effects in the post-seismic actions for the 2012 Emilia (Italy) earthquakes. Bull Earthq Eng 12(5): 2147-64

D'Ayala D, Speranza R., 2003. Definition of collapse mechanisms and seismic vulnerability of historic masonry buildings. Earthq Spectra 19(3): 479-509

Doglioni F, Moretti A, Petrini V., 1994. Le chiese e il terremoto - Dalla vulnerabilità constatata nel terremoto del Friuli al miglioramento antisismico nel restauro, verso una politica di prevenzione. Ed. LINT, Trieste - Italy (in Italian).

Ebhardt B., 1917. Die Burgen Italiens. Wasmuth, Berlin (in German)

Fantoni L., 2006. L'architettura fortificata in Friuli dopo il sisma del 1976. Forum Editrice Universitaria Udinese S.r.l., Udine - Italy (in Italian).

Gazzola P., 1976. La tregedia del Friuli. Castellum 18: 6974 (in Italian).

Guidelines, 2007. Guidelines for evaluation and mitigation of seismic risk to cultural heritage. Gangemi, Rome

Icastelli.it 2006. Castelli e Torri d'Italia. http://icastelli.it. Accessed 2 April 2017

I Luoghi del Silenzio 2016. http://www.iluoghidelsilenzio.it. Accessed 2 April 2017

Leoni G, Zona A, Piattoni Q, Meschini A, Petrucci E, Dall'Asta A, Dezi L., 2015. Assessment of seismic vulnerability of historical defensive walls. In: M. Papadrakakis, V. Papadopoulos, V. Plevris (eds.), 5th ECCOMAS Thematic Conference on Computational Methods in Structural Dynamics and Earthquake Engineering COMPDYN 2015, Crete (Greece) ISBN: 978-960-99994-7-2

Latini M., 2000. Guida ai castelli d'Abruzzo. Carsa, Pescara Italy (in Italian).

Mauro M., 1992. Castelli, rocche, torri, cinte fortificate delle Marche, Istituto italiano dei Castelli Sezione Marche, Ancona Italy (in Italian).

MiBAC Soprintendenza Generale agli interventi post-sismici in Campania e Basilicata. 1994. Dopo la polvere. Istituto Poligrafico e Zecca dello Stato, Roma (in Italian).
MiBAC 1998. Oltre il terremoto: primo repertorio di monumenti danneggiati dal sisma: Umbria 1997. Gangemi, Roma (in Italian).

MiBAC Direzione Regionale per i Beni Culturali e Paesaggistici delle Marche 2007. RiMarcando Tecnostampa, Loreto - Italy (in Italian)

MiBACT 2015. WebGIS del Patrimonio culturale dell'EmiliaRomagna. http://www.patrimonioculturale-er.it/webgis/. Accessed 17 April 2017

MiBACT 2016. Carta del Rischio http://www.cartadelrischio.it/eng/index.html. Accessed 17 April 2017

Michele M., Di Stefano R., Chiaraluce L., Cattaneo M., De Gori P., Monachesi G., Latorre D., Marzorati S., Valoroso L., Ladina C., Chiarabba C., Lauciani V. and M. Fares, 2016. The Amatrice 2016 seismic sequence: a preliminary look at the mainshock and aftershocks distribution. ANNALS OF GEOPHYSICS, 59, Fast Track 5, 2016; DOI: 10.4401/ag-7227

Mirabella Roberti R, Bondanelli M, Trovò F., 2012. A vulnerability index evaluation for masonry bell towers in Venice. in: J. Jasienko (Ed.), 8th International Conference on Structural Analysis of Historical Constructions SAHC 2012, Wroclaw (Poland), Dolnoslaskie Wydawnictwo Edukacyjne (DWE), Wroclaw, Poland, pp. 351-358

Mondi Medievali. 2016. http://www.mondimedievali.net. Accessed 2 April 2017

Monti A., 2006. Il GIS dei castelli dell'Emilia-Romagna: dalla georeferenziazione dei dati alla comprensione dello spazio degli uomini. CLUEB, Bologna - Italy. (in Italian).

Moretti A., 2008. Primi studi sulla vulnerabilità sismica dei castelli del Friuli Venezia Giulia. in V. Foramitti (Ed.), Restauri di Castelli, vol. 2, Gaspari Editore, Udine Italy, pp. 15-32. (in Italian).

Meschini A, Leoni G, Petrucci E, Sicuranza F, Zona A, Piattoni Q, Dezi L, Dall'Asta A., 2015. An integrated survey experience for assessing the seismic vulnerability of Senigallia's Fortress (Italy): documentation for conservation and FEM modeling. In Digital Heritage IEEE, Vol. 2, pp. 21-28.

PCM-DPC-MiBAC. 2006. Damage survey form for the cultural heritage - palaces and churches (adopted by the Department of Civil Protection), G.U. no. 55 07/03/2006, D.P.C.M. 23/02/2006 (in Italian).

Perogalli C., 1972. Castelli e rocche di Emilia e Romagna. Gorlich Editore, Milano - Italy. (in Italian).

QGIS Development Team. 2015. QGIS Geographical Information System. Open Source Geospatial Foundation Project. http://qgis.osgeo.org. Accessed 1 January 2016

Regione Umbria. 2015. Osservatorio Sulla Ricostruzione. http://www.osservatorioricostruzione.regione.umbria.it. Accessed 2 April 2017 (in Italian).

Rossetto T, Iannou I, Grant DN., 2013. Existing empirical fragility and vulnerability functions: Compendium and guide for 
selection. GEM Technical Report 2013-X, Fondazione GEM, Pavia Italy. http://www.globalquakemodel.org. Accessed 1 September 2016

Saisi A, Terenzoni S., 2014. Historic military architectures in the province of Mantua: the effects of the 2012 earthquakes. in F. Peña and M. Chávez (Eds.), SAHC2014 - 9th International Conference on Structural Analysis of Historical Constructions14-17 October 2014. Mexico City - Mexico

Santoro L., 1978. I castelli angioini della Campania. Castellum 19 (in Italian).

Sepe V, Speranza E, Viskovic A., 2008. A method for largescale vulnerability assessment of historic towers. Struct Control Health Monit 15: 389-415

Shakemap Working Group. 2016. Shakemap Homepage. http://shakemap.rm.ingv.it/shake/index.html. Accessed 2 April 2017

Simões A, Milošević, J, Meireles, H.a, Bento R, Cattari S, Lagomarsino S., 2015. Fragility curves for old masonry building types in Lisbon. Bull Earthq Eng, 13(10): 3083-3105

Tiberti S, Acito M, Milani G., 2016. Comprehensive FE numerical insight into Finale Emilia Castle behavior under 2012 Emilia Romagna seismic sequence: Damage causes and seismic vulnerability mitigation hypothesis. Eng Struct 117: 397-421

Valente M, Milani M., 2016. Seismic assessment of historical masonry towers by means of simplified approaches and standard FEM. Constr \& Build Mat 108: 74-104.
USGS
Shake
Maps.
http://earthquake.usgs.gov/earthquakes/shakemap/. Accessed March 2017 